\section{Potensiell biomarkør for multippel sklerose}

\begin{abstract}
IgM-antistoff mot s-nitrosocystein kan påvises i spinalvæsken hos mange pasienter med multippel sklerose og kan kanskje brukes diagnostisk i fremtiden.
\end{abstract}

Multippel sklerose (MS) er en demyeliniserende sykdom med sekundær nevrodegenerasjon. Det finnes ingen helbredende behandling, men tidlig sykdomsbegrensende behandling kan forsinke sykdomsprogrediering. Det er derfor ønskelig å finne markører som kan bidra til at diagnosen blir stilt så tidlig som mulig.

Under sykdomsforløpet av multippel sklerose dannes det immunglobuliner, og IgG kan påvises i spinalvæsken hos over $90 \%$ av pasienter med multippel sklerose. IgM vet man mindre om. Når sykdommen er aktiv, produseres nitrogenoksid (NO), en aktiv radikal som nitrosylerer aminosyren cystein og danner S-nitrosocystein. Tidligere studier har vist at det dannes et IgM-antistoff mot S-nitrosocystein. Dette antistoffet, kalt antiSNOcys, kan påvises i serum hos pasienter med multippel sklerose.

I en norsk studie ble anti-SNOcys påvist i spinalvæsken hos 13 av 22 pasienter med relapserende-remitterende multippel sklerose, mot ingen av 17 kontrollpasienter som var under utredning for annen nevrologisk sykdom (1). Anti-SNOcys-nivået korrelerte med tiden siden siste multippel skleroseatakk. Det var også en korrelasjon mellom spinalvæskenivå og serumnivå hos samme pasient.

- Denne pilotstudien kan tyde på at måling av anti-SNOcys-IgM kan brukes som en markør for multippel sklerose, sier Charlotte Hvaring, som er førsteforfatter av artikkelen. Dette er hennes første publikasjon. - Vi ønsker å undersøke nærmere om dette antistoffet finnes ved andre nevrologiske tilstander, bl.a. meningitt, encefalitt og hjerneslag. Det vil også være interessant å se nærmere på om det kan påvises hos pasienter ved første demyeliniserende episode, og om det eventuelt kan predikere hvem som senere utvikler multippel sklerose, sier Hvaring.

\section{Forskergruppen}

Studien er et samarbeid mellom Norges teknisk-naturvitenskapelige universitet (NTNU), St. Olavs hospital og University of Illinois at Chicago. Professor Anne Boullerne i Chicago forsker på multippel sklerose og humane gliaceller og har utviklet

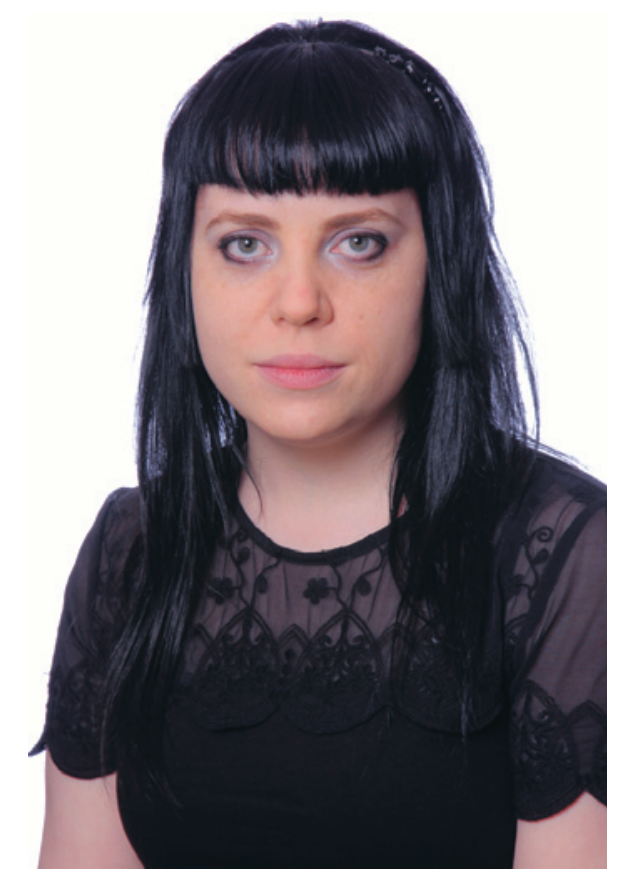

Charlotte Hvaring. Foto Elise Adamsrød

antistoffanalysen som ble brukt i studien. Professor Linda White er leder for Nevrobiologisk laboratorium på St. Olavs hospital og for Forskningsbiobanken, som blant annet inneholder spinalvæskeprøver fra pasienter med multippel sklerose. Samarbeidet ble initiert da White og Boullerne traff hverandre på en internasjonal konferanse. Professor Jan Aasly (St. Olavs hospital/NTNU) og professor Douglas Feinstein i Chicago har bidratt med sin nevrologiske kompetanse på hver sin side av dammen. Charlotte Hvaring er medisinog forskerlinjestudent ved Norges teknisknaturvitenskapelige universitet og interesserer seg for autoimmunitet og nevrologi.

\section{Hanne Støre Valeur}

hanne.store.valeur@legeforeningen.no Tidsskriftet

\section{Litteratur}

1. Hvaring C, Vujicic S, Aasly JO et al. IgM to S-nitrosylated protein is found intrathecally in relapsingremitting multiple sclerosis. J Neuroimmunol 2013; 256: 77-83.
Ordforklaringer

Biomarkør: En biologisk karakteristikk som måles objektivt og brukes som en indikator på normale biologiske prosesser, patologiske prosesser eller en farmakologisk respons på en terapeutisk intervensjon.

Relapserende-remitterende multippel sklerose (RRMS): Dette er den vanligste typen av multippel sklerose. Forløpet er karakterisert av sporadiske demyeliniserende episoder, med sykdomsfrie perioder imellom. Over tid akkumuleres det skade som ikke lar seg remyelinisere.

Nitrosylering: En kjemisk reaksjon der nitrogenoksid (NO) reagerer med biologiske molekyler, slik som proteiner. I vårt tilfelle reagerer nitrogenoksid med den svovelholdige gruppen på aminosyren cystein og danner S-nitrosocystein (SNOcys), noe som gir opphav til en immunrespons. Denne reaksjonen er en posttranslatorisk proteinmodifikasjon.

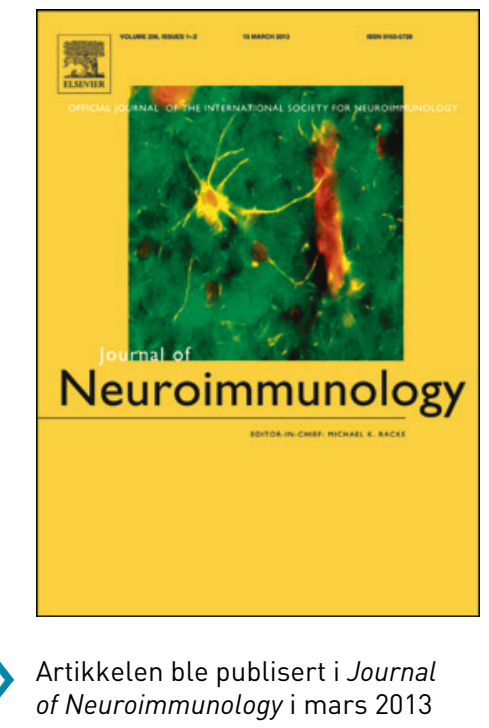

